\title{
Traços de espirógrafo: o cotidiano banal e a intransitividade social no conto "De forno a forno", de Rubens Figueiredo
}

\author{
Spirograph traces: the banal daily life and social intransitivity \\ in Rubens Figueiredo's "De forno a forno" \\ Rastros del espirógrafo: la vida cotidiana banal y la intransitividad \\ social en el cuento de Rubens Figueiredo "De forno a forno"
}

Abigail Ribeiro Gomes ${ }^{*}$

\section{Resumo}

Este artigo se propõe a observar alguns aspectos do uso de imagens esféricas no conto "De forno a forno", de Rubens Figueiredo. A proposição é verificar de que modo essas imagens contribuem na apresentação e na reiteração da banalidade e da intransitividade social do cotidiano da camada mais pobre da população retratadas na obra de Figueiredo, dentro de uma perspectiva do círculo como algo que simboliza o imutável, sem começo nem fim, nem variações. A utilização e a articulação das imagens esféricas no conto, assim como a própria estrutura circular adotada por Figueiredo na construção da narrativa, propõem, a nosso ver, um cerco e uma manutenção das classes sociais retratadas, consequentemente uma espécie de impedimento de transposição dessas classes, tanto socialmente quanto de pensamento.

Palavras-chave: “De forno a forno", imagens esféricas, intransitividade social, Rubens Figueiredo.

\begin{abstract}
This article aims to observe some aspects of the use of spherical images in the tale "De Forno a Forno", by Rubens Figueiredo. The proposition is to check the way these images contribute for the presentation and the reiteration of banality and social intransitivity in poor population's common life, exposed in Figueiredo's work, considering the circle as a symbol of something immutable, with no beginning nether end, and with no variations. We consider that the use and the articulation of spherical images in the tale, as well as the structure used by Figueiredo in the construction of the narrative, propose the siege and maintenance of the social classes exposed, consequently a kind of impediment for the transposition through these classes, even socially or of thinking.
\end{abstract}

Keywords: "De forno a forno", spherical images, social intransitivity, Rubens Figueiredo.

\begin{abstract}
Resumen
Este artículo se propone a observar algunos aspectos del uso de imágenes esféricas en el cuento "De Forno a Forno", de Rubens Figueiredo. La proposición es verificar de qué modo esas imágenes contribuyen en la presentación y en la reiteración de la banalidad y de la intransitividad social del cotidiano de la capa más pobre de la población retratadas en la obra de Figueiredo, dentro de una perspectiva del círculo como algo que simboliza lo inmutable, sin comienzo ni fin, ni variaciones. La utilización y la articulación de las imágenes esféricas en el cuento, así como la propia estructura circular adoptada por Figueiredo en la construcción de la narrativa, proponen, a nuestro ver, un cerco y un mantenimiento de las clases sociales retratadas, consecuentemente una especie de impedimento de transposición de esas clases, tanto socialmente como de pensamiento.
\end{abstract}

Palabras-clave: "De forno a forno", imágenes esféricas, intransitividad social, Rubens Figueiredo.

\footnotetext{
" Doutoranda em Literatura Brasileira na Universidade Federal do Rio de Janeiro (UFRJ), Rio de Janeiro, RJ, Brasil. (Dorcid.org/0000-0003-1269-9149. E-mail: abigailrib@gmail.com
} 
Tem dias que a gente se sente / Como quem partiu ou morreu / A gente estancou de repente / Ou foi o mundo então que cresceu / A gente quer ter voz ativa / No nosso destino mandar / Mas eis que chega a roda-viva / E carrega o destino pra lá / Roda mundo, rodagigante / Roda-moinho, roda pião. / O tempo rodou num instante / Nas voltas do meu coração.

Chico Buarque

\section{Roda mundo, roda-gigante}

"Imutável, sem começo nem fim, e nem variações". Assim é apresentado o círculo na página 250 do Dicionário de símbolos, de Jean Chevalier. E é a partir dessa ideia que este artigo se propõe a observar como as imagens esféricas colaboram no conto "De forno a forno", constante do livro Contos de Pedro, de Rubens Figueiredo, para a apresentação e reiteração da banalidade e da intransitividade social do cotidiano da camada mais pobre da população.

Por se tratar de um texto que se propõe a observar o movimento do cotidiano na obra literária, a trajetória do escritor em questão torna-se pertinente. E a de Rubens Figueiredo é peculiar. Dau Bastos observou O caso Rubens Figueiredo apontando dois momentos distintos da produção do ficcionista: primeiramente, com a escrita do que Bastos chamou de "trilogia trepidante", construída com "universos distantes de sua própria existência" (Bastos, 2019?, p. 2), composta por O mistério da samambaia bailarina, de 1986, Essa maldita farinha, de 1987, e A festa do milênio, de 1990. O segundo momento, inaugurado em 1994 com O livro dos lobos, caracteriza-se como um "movimento espiralado da especulação sobre a existência" (Bastos, 2019, p. 4).

Contos de Pedro, publicado em 2006, enquadra-se nesse segundo momento "espiralado". O crítico apontou a coletânea de contos aqui abordada como "disposta a se engalfinhar com a realidade, mas não para se negar como arte, e sim para combinar ausculta e invenção" (Bastos, 2019, p. 7), num trabalho de linguagem enxuta e construção frasal precisa, objetiva e milimetricamente talhada. Trata-se de uma coletânea de nove contos cujos protagonistas têm o nome de Pedro - exceção a "Alegrias da carne". Dau Bastos $(2019$, p. 7) chama a atenção para essa recorrência ao nome - tanto em Contos de Pedro quanto no romance subsequente, Passageiro do fim do dia, de 2010 - apontando que o "prenome indica um ponto de vista e uma condição". A rigidez e a proximidade com o chão denotadas pelo significado de "pedra" e a recorrência do nome no contexto brasileiro em particular reforçam a condição de banalidade e o ponto de vista de rés do chão. Nas histórias da coletânea, a visão apresentada é sempre a de Pedro, seja o Pedro personagem-narrador ou o Pedro personagem a cuja perspectiva o narrador adere.

Outra particularidade de Contos de Pedro: em primeira ou terceira pessoa, o narrador é o "dono" da história, porque sua voz é a única que se escuta em quase todos os contos - o único que apresenta diálogos entre personagens é "Céu Negro". Assim, a voz de Pedro/pedra tornase audível pelo narrador, que apresenta a perspectiva de rés do chão. Apesar de partir do ponto de vista de Pedro, o narrador apresenta os contos de forma "indiferente - ou no máximo permitindo-se uma curiosidade distante"; conforme considerou Cristóvão Tezza. Ainda segundo Tezza, esse narrador desdobra "seus 'pedros' [...] como quem apenas conta casos, quem sabe curiosos, mas despersonalizando-os ao osso, numa autópsia dos sentidos". Esses sentidos eram perspectivados "por 'pedros' angustiantemente estrangeiros", que apresentavam um olhar quase antropológico ao contexto em que se inseriam, olhar este reforçado pela aparente indiferença do narrador.

A distância do ponto de vista do narrador é ponto-chave da utilização das imagens esféricas metaforicamente utilizadas por Figueiredo no conto "De forno a forno" e determina em vários momentos a dimensão da esfera como sendo o narrador que "assume o fazer ouvir um sujeito ao mesmo tempo insistente e insituável, desconhecido e no entanto reconhecido segundo uma inquietante familiaridade" (Barthes, 2010, p. 21). Trata-se de um jogo de escritor-narradorpersonagem em que "as palavras não são mais concebidas ilusoriamente como simples instrumentos, são lançadas como projeções, explosões, vibrações, maquinarias, sabores: a escritura faz do saber uma festa" (Barthes, 2010, p. 21). 
Anteriormente, mencionamos a construção frasal de Rubens Figueiredo como sendo um trabalho de linguagem enxuta e construção frasal precisa, objetiva e milimetricamente talhada, ou seja, "a violação da forma é inerente a seu próprio sentido" (Adorno, 2003, p. 60). Essa aparente ausência de causalidade na forma adotada por Figueiredo na elaboração frasal dialoga com o acaso banal e o ritmo cadenciado da vida cotidiana. Assim, numa obra que direciona seu olhar à intransitividade social e à recorrência do banal, o ritmo mecânico e lento oferece ao leitor a possibilidade do desespero de um mundo sem escolhas, mesmo sem que esse desespero seja observado no texto, que se apresenta sem nenhuma altissonância. Partindo-se do pressuposto de que a criação artística verbal e "a própria linguagem é o horizonte insuprimível de 'nosso mundo', que põe em perspectiva todos os outros e possíveis mundos" (Stierle, 2006, p. 88), Rubens Figueiredo se utiliza de uma emolduração da realidade, considerando que "pelo parêntese é sempre assinalada a presença de um aspecto da totalidade que, de sua parte, não pode ser uma qualidade do mundo representado, no mínimo porque este foi constituído a partir de segmentos dos diversos sistemas contextuais do texto" (Stierle, 2006, p. 43-44). Essa emolduração, esse colocar "entre parênteses" que permite a superação da realidade, ao mesmo tempo que assinala um aspecto de totalidade.

A proposição de leitura do conto "De forno a forno" se equilibra sobre a forma esférica, oscilante na sustentação da física, porém firme na manutenção do status social. E, como se pode observar em todo o livro, o conto escolhido não foge à regra da coletânea no que se refere ao protagonista e à sua posição social. Georgina Martins observou que, "como em toda obra de Rubens Figueiredo, aqui não há espaço para o estardalhaço, tampouco a realidade é transformada em matéria de espetáculo" (Martins, 2013, p. 134), ao contrário, a escrita de Figueiredo se mantém na precisão e justeza que lhe são características. A banalidade cotidiana fica evidente na abordagem de reflexões que "saltam da observação do crescimento da ferida do mendigo que se colocava em seu caminho até o forno da minúscula lanchonete dos pais, onde as empadas eram diariamente assadas" (Martins, 2013, p. 135). A circularidade cotidiana foi evidenciada conforme o ficcionista construiu a narrativa, de modo que, "pontuando o doído crescimento do menino, passavam as feridas dos diversos mendigos, as incontáveis empadinhas e a separação e reconciliação dos pais, como se cada evento misteriosamente anunciasse o seguinte, às vezes mais duro e mais penoso que o anterior" (Martins, 2013, p. 136). A intransitividade social se evidencia conforme "ferida, empadas, forno e a moedinha na tigela do mendigo convertem-se em metáforas da degradação que corrompe aquele mundo ordinário, previsível e pobre que o cerca" (Martins, 2013, p. 135).

Considerando as observações feitas por Georgina Martins, pode-se supor encontrar em "De forno a forno" uma pluralidade de discursos, construídos conforme se desenvolve a compreensão do texto que, "à medida que se debruça sobre o fenômeno simbólico, não se contenta com um discurso monolítico. Postula o princípio de que a forma verbal do signo é aparente, mas não transparente" (Bosi, 2003, p. 475). Assim, a pluralidade do discurso - que articula feridas, empadas, fornos e moedas - processa-se no campo simbólico, considerando o que Alfredo Bosi diz a respeito do símbolo: "ao mesmo tempo exprime e supõe, revela e oculta; explicita, mas traz implícito um processo subjetivo e histórico que o funda e o ultrapassa" (Bosi, 2003, p. 475).

Na proposição de articular o símbolo do círculo aos demais símbolos utilizados no conto de Rubens Figueiredo, torna-se pertinente partir da premissa apontada por Alfredo Bosi, assim como sua compreensão de que a obra literária "valoriza sempre o modo de aparecer do símbolo, a sua epiphania, porque essa constelação de perfis, ou de aparições, tem a ver com os modos de ser do universo simbolizado" (Bosi, 2003, p. 476). O símbolo do círculo é o articulador dos demais símbolos, de modo que, através dele, sejam colocados em molduras que permitam uma observação mais profunda sobre a banalidade do cotidiano e a intransitividade social.

$\mathrm{O}$ fecho que a figura do círculo sugere, o estar circunscrito num determinado limite fechado, tem na construção estética sua concretização. A asfixia do cerco fechado do círculo foi observada por Dau Bastos, ao apontar o fato de que Figueiredo "suprimiu os arejantes diálogos, trocados por parágrafos que, sempre compostos de frases curtas e palavras simples, mostram-se densos devido ao caráter indagativo" (Bastos, 2019, p. 4). 
Fechando o rol de comentaristas sobre "De forno a forno", Karla Louise de Almeida Petel pontuou um fator determinante para as observações subsequentes, ao considerar que "o detalhe não é só um simples componente da obra" (Petel, 2015, p. 43), mas objeto de observação de um "exame do ambiente degradante" (Petel, 2015, p. 44) em que as personagens estão inseridas. Esse contexto degradante "é perpetuado justamente pela presença desses aspectos da ordem do habitual, que geram movimentos cíclicos e sem saída" (Petel, 2015, p. 44).

\section{Roda-moinho, roda pião}

Algumas informações sobre a narrativa em questão são necessárias. Rubens Figueiredo lançou mão de um narrador em terceira pessoa ciente somente do que se passa com o protagonista Pedro, um menino que vive algumas situações corriqueiras no universo social em que está inserido, no contexto urbano periférico em alguma cidade brasileira, não determinada no texto. $\mathrm{O}$ narrador apresenta essas situações em perspectiva de aproximação e distanciamento, de expansão e contração, que permitem diferentes percepções sobre a passagem do tempo, sobre a relevância dos fatos, sobre a banalização das dores e dos amores, sobre a imutabilidade dos papéis sociais.

As situações pelas quais passa ou nas quais observa o menino Pedro são organizadas em duas fases que se subdividem em três círculos, os quais se repetem nas duas fases da narrativa, nos movimentos de contração e expansão. Esses círculos também têm como ponto de interseção a própria figura de Pedro, e cada círculo tem uma imagem esférica como símbolo.

- O primeiro círculo é do pertencimento de Pedro a uma fase da vida: na primeira fase, Pedro e sua circulação na escola; na segunda fase, Pedro e a namorada. Neste círculo, os símbolos são a movimentação na escola e os dois "círculos" da namorada - pinta e vagina - , respectivamente.

- O segundo círculo é o dos mendigos: na primeira fase, o primeiro mendigo e sua ferida; na segunda fase, o segundo mendigo, sua ferida e a mendiga. No segundo círculo, o símbolo é o mesmo para as duas fases, a ferida na perna dos mendigos.

- O terceiro círculo é o dos pais de Pedro: na primeira fase, o casamento estável, apesar de enfadonho; na segunda fase, a repetição de reatar-romper. Nesse terceiro círculo, são dois símbolos que aparecem em ambos os momentos, empadas e forno, porém com oscilação de importância em algumas passagens da narrativa.

A numeração proposta aqui tem caráter apenas instrumental, pois o conto não apresenta, em cada fase, os três círculos em sequência, mas em suas interseções, em movimento de rotação de cada círculo e de translação em torno da figura de Pedro. Esse movimento, que aqui chamamos de translação, é o que permite a interseção entre os círculos em cada fase. Essas considerações tecidas aqui serão paulatinamente desmembradas e exemplificadas adiante no texto.

Sobre a primeira fase: o conto se inicia com a tomada de ponto de vista, de perspectiva. A narração menciona o mínimo e próximo, distancia-se e vai se aproximando ao centro novamente, até chegar ao mínimo no fundo do círculo:

O ponto preto no meio do alvo. O tiro na mosca. O coração dos círculos concêntricos, que se estreitam um a um: do céu para as nuvens; de lá para o terraço dos prédios; depois, para as fileiras de janelas, nos dois lados da rua, em círculos que descem e diminuem, andar por andar, rumo à marquise e ao letreiro das lojas; daí, direto para a borda da tigela redonda sobre as pedras da calçada e, por último, para a moeda, que faísca no fundo da tigela (Figueiredo, 2006, p. 31).

Observa-se nessa citação o movimento que caracteriza a perspectiva do narrador no decorrer de todo o conto, ou seja, sendo um narrador em terceira pessoa, supostamente onisciente, tem a possibilidade de observar e narrar com o distanciamento que a altura proporciona; porém, opta pela aproximação da perspectiva do protagonista, "Pedro", eixo de convergência dos círculos rotativos. Essa movimentação de expansão e contração da perspectiva reitera-se na seguinte passagem: 
Pedro, também com o passo já desembaraçado e no mesmo impulso dos demais, via então se alargarem, uma a uma, as suas impressões, que por um instante ficaram encolhidas naquele funil: a moeda, a ferida, a tigela, as marquises, as fileiras de janelas, o terraço dos edifícios - o céu (Figueiredo, 2006, p. 32).

Observa-se que o narrador declaradamente expõe a visão de Pedro, expandindo a perspectiva, aí chamada de "impressões", como se o narrador entregasse a Pedro um binóculo capaz de aproximar e distanciar a visão, para que ele, narrador, possa apresentar o ponto de vista de Pedro ao leitor.

As duas passagens citadas estão relacionadas à aparição do primeiro mendigo da narrativa, ou seja, com a abertura do primeiro círculo, que tem a ferida como figura esférica símbolo: “Algum calor trabalhava por dentro e, mês a mês, a ferida mudava de feição. O vermelho roía a pele negra pelas beiradas e, no centro, uma gota esbranquiçada queria abrir caminho para o fundo" (Figueiredo, 2006, p. 32-33). A ferida crescia e, de modo inversamente proporcional, o mendigo encolhia: "O homem minguava. Até que um dia, ao passar por ali a caminho da escola [...] Pedro olhou com atenção e não viu a gota pendurada na ponta do nariz. Viu apenas as narinas imóveis, bordadas de rachaduras secas. Quando Pedro voltou, horas depois, o homem não estava mais lá" (Figueiredo, 2006, p. 45). A consumição do homem pela ferida se dava como se o círculo o engolisse, evidenciando a exiguidade da vida perante a força da recorrência da dor.

O lugar do mendigo na rua era junto ao muro de uma escola - não a de Pedro, mas uma que ficava no caminho entre a casa de Pedro e a escola onde ele estudava. A interseção do primeiro círculo do mendigo com o primeiro círculo de Pedro-menino ocorreu na movimentação: o mendigo atravancava a passagem de Pedro para a escola. E o Pedromenino, frequentador da escola, estabelece sua ciranda dentro desse espaço:

A escola continuava a mesma, mas Pedro e sua turma, a cada nova série, mudavam de sala no casarão. Essa trajetória dos alunos de sala em sala pelo interior do prédio, com etapas anuais bem marcadas e previsíveis, sugeria um projeto de constância. E a isso ainda somava os atrativos de uma missão e de um prêmio. Só muito aos poucos, e só quando já era tarde demais, os alunos descobriam: eles mesmos eram as peças trocadas em cada ciclo. Eles mesmos eram o trajeto, e não quem o percorria. E só então se davam conta de que era esse o único prêmio (Figueiredo, 2006, p. 44).

O narrador deixa evidente o movimento circular de Pedro e seus colegas dentro da escola, principalmente com a utilização dos termos "ciclo" e "trajeto". A caracterização de Pedro e os demais alunos como sendo o próprio trajeto cíclico atribui a essas personagens a imagem circular. A demarcação e previsibilidade das etapas, bem como a tradição do prédio da escola reforçam a constância do movimento circular e, consequentemente, a caracterização das personagens como esferas. Indo além da passagem citada, o fato de Pedro ser um aluno que se posiciona em enfrentamento com o sistema escolar e que é, recorrentemente, aprovado nas últimas oportunidades do ano letivo corrobora com sua caracterização em círculo, em função de sua postura redundante frente aos estudos. Como se a pedra-Pedro estivesse sendo rolada de etapa em etapa para a construção do trajeto circular.

O rendimento escolar de Pedro era um dos motivos das brigas entre seus pais. Todavia, não era o principal: as empadas tinham protagonismo nos embates. Ambos, pai e mãe, inseridos no terceiro círculo de construção da narrativa, giraram sua participação em torno das empadas que, embora fossem o mais recorrente ponto de discórdia, foram também o pretexto de sua aproximação e seu casamento. Assim, a preciosidade da iguaria foi evidenciada na apresentação de sua relevância no movimento repetitivo do cotidiano familiar:

As empadas, suas irmãs, o sangue da sua mãe. Nem sempre elas conseguiam pagar em dia a mensalidade da sua escola. Na verdade, elas mal conseguiam pagar o custo das horas do dia em que vinham ao mundo - o mesmo dia em que eram destruídas com voracidade. $\mathrm{E}$ sempre mais empadas reclamavam mais bocas - e mais bocas chamavam mais empadas. $\mathrm{E}$ sempre o dinheiro rápido nas mãos do pai - notas e moedas que ferviam na gaveta quando os dedos do pai iam vasculhar, até o fundo, em busca de troco. O dinheiro rápido para subornar o fiscal, que saboreava de pé uma empada enquanto o pai fechava uma 
embalagem de isopor - mais de meia dúzia de empadinhas, para o fiscal levar para casa ou dar de presente a alguma mulher (Figueiredo, 2006, p. 34).

As empadas formam o eixo do movimento rotacional desse terceiro círculo, a partir de seu papel motor, como se observa na engrenagem reproduzida na citação. Assim como são elas que provêm, também são elas que exaurem os elementos da família. Por ser um item alimentício e, principalmente, o item do comércio, elas evidenciam as ranhuras no sistema capitalista, que suga e oprime as classes desprivilegiadas. E, nesse caso, assim como o símbolo esférico dentro da narrativa, reforçam a impossibilidade de libertação do círculo vicioso em que estão as personagens que giram ao seu redor - de trabalho, carestia, suborno em rotatividade.

$\mathrm{O}$ "aperto" por que passam Pedro e sua família; o "aperto" por que passam Pedro e seus colegas; a contração por que passa o mendigo, até a sua extinção: o primeiro momento do conto se caracteriza pela rotação dos três círculos em torno de seu símbolo-eixo e em torno do protagonista Pedro, tendo como movimento mais recorrente a contração, ou o "aperto", como se pode ver nas considerações anteriores. Antecedendo os desfechos dos três círculos do primeiro momento - quais sejam, o primeiro rompimento dos pais de Pedro, a aprovação escolar de Pedro e a morte do mendigo - o narrador faz uma articulação desses círculos:

Uma honra, um acinte - um dever cumprido. Ou que se cumpre aos poucos, dia a dia, sem ninguém notar. E, de fato, para Pedro, aqueles dias não admitiam, por nada neste mundo, manter-se separados uns dos outros. Em vez de passarem, em vez de cada dia ceder seu lugar ao dia seguinte, eles se depositavam uns dentro dos outros, misturavam-se, gota a gota, em uma única poça, cada vez maior e mais funda. Era mais do que um sinal - era uma certeza. Porque, cedo ou tarde, tinha de chegar essa hora. A hora em que o mundo espalhado das coisas se junta, se levanta com todo o seu peso e barra o caminho. A hora em que as pontas dos pés, debaixo da água, procuram o fundo para se apoiar e não mais o encontram (Figueiredo, 2006, p. 39).

Observe-se nessa passagem a menção a ajuntamento - ou aproximação: a junção dos dias, do "mundo espalhado das coisas", que, apesar de juntos, formavam a poça "cada vez maior e mais funda" ou o fundo debaixo da água em que não se pode apoiar porque não é encontrado. Os movimentos de contração e expansão se confundem de modo a desestabilizar o protagonista, ao mesmo tempo em que o mantêm fechado no círculo. $\mathrm{O}$ movimento de tornar mais amplo e mais apertado, mais fundo e mais raso, corrobora com a definição do ponto de vista do narrador: ora próximo do que se passava com Pedro, ora observador indiferente, novamente como as lentes de um binóculo.

Vale atentar-se para outro pormenor da passagem acima: "a hora em que o mundo espalhado das coisas se junta, se levanta com todo o seu peso e barra o caminho". O mundo, ajuntado e pesado, barra o caminho, ou seja, impede a transição, fecha o cerco, aprisiona num raio limitado. "Cerco" e "raio" são dois termos relacionados semanticamente ao círculo, formatrajeto percorrido pelas personagens do conto. Tal proposição, de manutenção das personagens circunscritas em círculos definidos, é corroborada pela seguinte passagem:

No dia-a-dia, o caminho de Pedro, sempre repetido, da casa até a escola e depois de volta para a loja dos pais, enganchava com firmeza um ciclo no outro. Os passos de Pedro pela rua o levavam para o ciclo novo, mas sem que ele pudesse abandonar, de fato, o ciclo anterior (Figueiredo, 2006, p. 44).

O verbo enganchar, da oração principal do primeiro período do trecho aqui reproduzido, tem como sujeito "o caminho de Pedro", atribuindo a esse sujeito o protagonismo da ação de enganchar "com firmeza um ciclo no outro". Lido dessa forma, o período atribui à personagem a passividade de apenas obter o caminho e não a ação de atrelar um ciclo ao outro, de modo que ele, Pedro, esteja fechado dentro desses ciclos, que são, segundo o próprio narrador, subsequentes, interdependentes e interseccionados.

Seguindo o que o narrador apontou - de que um novo ciclo não abandona o anterior - a narrativa passa para outra etapa. A marca desta divisão é a seguinte passagem: 
Um círculo dentro de outro círculo e o ponto negro no centro: Pedro, como qualquer um, sabia reconhecer a marca do fim. Mas, como qualquer um, se perdeu, se dispersou, ao tentar lembrar exatamente como as coisas tinham chegado àquele ponto e o que havia no começo. Experimentava e errava. Na verdade o erro esperava, pronto e acabado, desde o início, no experimento. O erro era o dote da tentativa (Figueiredo, 2006, p. 45).

A marcação do movimento circular da vida de Pedro, feita nessa passagem, além de corroborar com esta opção de leitura, apresenta outra proposição, a respeito da própria circularidade. Em sendo círculo, não existe exatamente início ou fim, de modo que esses limites não sejam claramente definidos; como se a circularidade do texto provocasse certa vertigem a ponto de confundir a compreensão e a abrangência da leitura. A menção à tentativa e ao erro como partes de um experimento reitera a sensação de circularidade e de difusão da percepção dos limites de começo e final. Além disso, a marca gráfica do ponto negro no centro do círculo, como um ponto final cercado da forma definidora da narrativa, ratifica a observação sobre a perspectiva de encolhimento e de expansão, de modo que se possa entender que "a marca do fim" pode não ser exatamente o fim, mas o recomeço, mediante a dispersão que dificulta a visão precisa.

O segundo momento da narrativa é menor em extensão textual, porém o narrador apresenta o que já havia antecipado, ou seja, a expansão do primeiro momento. Por ser o segundo momento "enganchado" ao primeiro, algumas observações não se fazem necessárias. Os três círculos do primeiro momento são o ponto de partida dos seus subsequentes, que têm, cada um, seu eixo de rotação. O primeiro círculo se abre com uma ausência, em oposição ao que aconteceu no primeiro momento. A ausência do "rei da rua", o mendigo morto, foi a primeira observação do narrador:

A rua não tinha mais rei. Pedro não precisava mais se desviar, passava direto junto ao muro, na corrente geral dos pedestres. Mas alargava o passo, ou desviava ligeiro a perna, para não deixar o pé tocar na mancha escura sobre o chão. E mesmo mais tarde evitava pisar ali, mesmo quando só restava, nas pedras da calçada, um sombreado sujo. O muro ia ser repintado e pichado de novo - ele sabia (Figueiredo, 2006, p. 45-46).

Apesar da ausência do mendigo, Pedro o fazia presente, pela resistência em pisar na mancha deixada pelo mendigo, mesmo quando ela já estava se apagando. De alguma forma, pode-se observar a antecipação da chegada do segundo mendigo, tanto pela postura de Pedro diante das marcas da presença do mendigo morto quanto pela frase "o muro ia ser repintado e pichado de novo - ele sabia". O narrador deixa o espaço livre e renovado para que um novo elemento possa ser inserido e vir a ocupar esse espaço. "Exatamente no mesmo ponto, sobre a mesma mancha que já estava lá, como se fosse um lugar marcado: um outro homem, o novo rei da rua" (Figueiredo, 2006, p. 48).

Assim como aconteceu no primeiro momento, o eixo desse círculo é a ferida. Um trecho deixa evidente a relevância desse eixo: "A ferida dava força de lei ao reinado do homem, e Pedro soube desde o primeiro instante que ela estava em atividade acelerada. $\mathrm{O}$ centro queria engolir a circunferência" (Figueiredo, 2006, p. 48). Observe-se que é a ferida-círculo que domina o rei-mendigo, garantindo seu domínio sobre o espaço, ao mesmo tempo que ela o corrói em atividade acelerada. De igual maneira, Pedro tinha o domínio sobre o que se sucederia com a ferida e com o mendigo, numa referência a passagens anteriores, de "enganchamento" de um círculo ao outro. Além disso, assim como um círculo se "engancha" no outro, o segundo expande o primeiro, mesmo que, em algum momento, haja o movimento de contração. E a velocidade é o primeiro indício de expansão desse círculo com relação ao círculo do primeiro momento, como se a força da ferida fosse potencializada.

Entretanto, antes de acontecer a expansão mais contundente desse círculo, houve a contração do mendigo e a expansão da ferida. Repetindo o acontecido com o primeiro mendigo e contrariando o receio de Pedro, de que "a perna atravessada na passagem não cumprisse o que tantas vezes havia prometido" (Figueiredo, 2006, p. 50), a perna "continuou a inchar e um dia, ao ir para a escola, Pedro viu que o homem não estava mais na calçada: só havia a mancha nas pedras do calçamento e outra mancha no muro" (Figueiredo, 2006, p. 50). O inchaço da perna foi 
inversamente proporcional ao encolhimento do mendigo que, primeiramente desapareceu e, na sequência da narrativa, retornou ao "mesmo lugar da calçada. Sem a ferida, sem a perna, com a calça imunda dobrada para dentro até a metade da coxa, arrematada por um coto" (Figueiredo, 2006, p. 50-51). Nesse trecho, vê-se o movimento de expansão do elemento central do círculo aqui designado - a ferida - de modo a estabelecer uma sujeição do outro elemento do círculo - o mendigo. Subvertendo a lógica, de que o ser dominaria aquilo que lhe "pertence", é a ferida que cresce em detrimento do homem, que encolhe. Repete-se, até aqui, o acontecimento do primeiro momento do conto, porém narrado com celeridade, a mesma que caracterizou a devoração do homem por parte da ferida.

O último fato narrado desse círculo é a grande expansão, a inclusão de mais uma personagem, uma mendiga, que disputa território com o segundo mendigo.

$\mathrm{O}$ mendigo perneta, abatido e quase sem forças, tentava reagir aos gritos da mulher pedinte que também queria instalar ali o seu ponto. A touca preta do homem estava rasgada. Via-se, por trás da lã, o crânio calvo, crivado de bolhas e calombos inflamados. A mulher, de camiseta e calção com manchas de fogo, tinha como sempre na boca uma chupeta de bebê. Mesmo com a chupeta na boca, gritava: "eu te corto a cara", "eu te furo todo". Pedro viu como ela ameaçou tomar a muleta do mendigo, numa lógica muito natural: primeiro sem perna; depois sem muleta. Por causa de um gesto brusco da mulher, o caco de espelho em que o homem gostava de se ver refletido se espatifou na calçada. O estilhaçar do vidro foi a última coisa que Pedro percebeu, enquanto caminhava em frente, sem parar, junto com os outros pedestres - para longe de tudo aquilo (Figueiredo, 2006, p. 52).

A inserção da mendiga nesse círculo transfere o conflito de Pedro perante o mendigo para os dois mendigos entre si. Pedro, que se dirige "para longe de tudo aquilo", não estabelece mais seu incômodo com a situação do mendigo, apenas faz conjecturas. O conflito entre o protagonista e o mendigo, evitado no primeiro momento do conto, se consuma com a inserção da mulher, expandindo o círculo anterior, que não chegou à consumação. Isso se deu justamente no momento de fragilização do mendigo mediante a ferida e, mais ainda, com a multiplicação da ferida em várias outras, espalhadas por outros lugares do corpo, como "o crânio calvo, crivado de bolhas e calombos inflamados". Interessante observar a expansão da ferida, eixo desse círculo, evidenciada na proliferação e na possibilidade de mais feridas, com as ameaças da mulher, de cortar e furar o mendigo. Novamente, os movimentos de expansão e de contração se alternam dentro do círculo, predominando a expansão com relação ao círculo anterior.

O segundo círculo a ser observado nesta etapa é o que abrange os pais de Pedro. Na apresentação desse círculo no segundo momento da narrativa, o narrador menciona a descoberta de Pedro, fazendo uma associação dessa descoberta à ferida do mendigo. Vamos iniciar a citação do trecho que nos interessa partindo de uma frase relacionada ao círculo mencionado anteriormente:

O centro queria engolir a circunferência. A mesma atividade que Pedro, naquela ocasião, descobriu também em casa: o olhar nebuloso que a mãe prolongava no marido, no filho, na loja e nas empadas, o olhar que a cada dia reconhecia um pouco menos de tudo. Mais alguns dias se passariam até que, como de outras vezes, e como tinha mesmo de ser, viesse a manhã em que a mãe não estaria na cozinha da loja, mas em algum ponto da rua, com o cigarro aceso na mão erguida e meio dobrada para trás. E até que viesse a noite em que o pai não estaria em casa, como costumava ficar - sentado no sofá, diante da tevê e na frente de um banco, sobre o qual apoiava as pernas coalhadas de varizes por ter de trabalhar em pé o dia inteiro (Figueiredo, 2006, p. 49).

Antes de tratarmos da associação entre os dois círculos, observemos a menção do narrador sobre a situação doméstica. O ambiente se manteve instável: "como de outras vezes" foi a expressão utilizada para vincular este círculo ao seu referente no momento anterior do conto. A menção ao rompimento dos pais, portanto, é o ponto de partida para a apresentação desse círculo. Mesmo os fatos apresentados na citação destacada há pouco são os que apareceram no momento anterior da narrativa. 
Porém, a iniciação desse círculo foi feita com a frase "o centro queria engolir a circunferência". Pode-se considerar que essa frase antecipa o eixo desse círculo novo, mencionado em passagens subsequentes: o novo forno.

No fim daquela semana, sua mãe ganhou um forno novo, como tanto queria. Um forno maior, mais quente, para empadas mais rápidas. A mãe tinha voltado a trabalhar na loja algum tempo antes. O pai também dormia de novo em casa e o trabalho de todos duplicara. Os tabuleiros com as forminhas enfileiradas entravam ordenadamente no forno. Tinham agora de ser colocados num local exato, já marcado lá dentro, e bastava o rápido abrir e fechar da porta do forno para Pedro sentir como o calor dos bicos de gás acesos abarcava a cozinha inteira, a loja, a família toda, até o fundo dos quartos de sua casa (Figueiredo, 2006, p. 50).

A expansão desse círculo, cujo centro engole a circunferência, ocorre com a chegada do forno. Esse eixo do círculo aqui abordado consumou o reatar das relações familiares, acelerou a produção das empadas - "irmãs" de Pedro -, dominou tanto o trabalho familiar quanto o espaço doméstico. As três personagens tiveram sua trajetória dentro do círculo delimitada pelo forno. Assim como a ferida, o forno foi apresentado como agente e as personagens como sujeitos pacientes, a ponto de a celeridade do forno interferir na velocidade com que seus movimentos na narrativa foram desempenhados. Entretanto, a organização implementada pelo forno, destaque da citação acima, também gerou um momento de crise:

O forno maior, como era de prever, levou a mãe primeiro ao entusiasmo e depois ao pânico. Seu horror ao marido e à cozinha foi proporcional aos poderes do forno. A crise, dessa vez, desorganizou o trabalho a tal ponto que o pai pediu que Pedro ficasse na loja no domingo, para limpar e arrumar tudo, enquanto ele ia cuidar de outros problemas urgentes (Figueiredo, 2006, p. 51).

Assim como ocorreu no círculo anterior, a expansão do eixo levou as personagens a um conflito: "primeiro ao entusiasmo e depois ao pânico". A dimensão do forno extrapolou as possibilidades viáveis, chegando a exercer seu poder sobre o casal, primeiramente, e sobre a loja, em segundo lugar. Esse rompimento dos limites do forno-eixo se deu do mesmo modo como ocorreu com as feridas do mendigo, causando uma instabilidade entre as personagens do círculo, vulnerabilizando-as ao seu poder.

O último círculo desse segundo momento é o que rege os demais círculos, articula-os e toma mais espaço da narrativa, diferentemente do que ocorreu no primeiro momento, em que os círculos tiveram espaços equiparados. Esse terceiro círculo é a consumação de um fato mencionado ainda no primeiro momento: o crescimento de Pedro. "O que nunca poderia ter entrado nos cálculos e nas previsões de Pedro era como, quase de um dia para o outro, ele ia ficar grande" (Figueiredo, 2006, p. 41) pode ser considerado o anúncio do que se consumaria nesse segundo momento, com a aparição de uma nova personagem: a namorada de Pedro. Na sua apresentação, o círculo que a identifica é a pinta na testa, "um olho extra, que vigiava os de baixo" (Figueiredo, 2006, p. 46). Todavia, essa pinta não reaparece na narrativa e é substituída, enquanto círculo-eixo, pela vagina da menina, caracterizada pelo narrador como "uma ferida quente, afunilada" (Figueiredo, 2006, p. 52). A movimentação de Pedro na narrativa passa a girar em torno da menina, mesmo nos momentos em que ele, como elemento de interseção, tem contato com os elementos dos outros círculos. Observe-se a seguinte passagem:

A ferida parecia pior a cada manhã, quando Pedro voltava da escola para ir correndo entregar as empadas, aflito com os minutos contados, um a um, na ânsia de que conta os próprios fios de cabelo. Os minutos do tempo em que às vezes conseguia ficar escondido com a menina no canto da escada, entre um andar e outro, no edifício onde ela morava (Figueiredo, 2006, p. 49).

O segundo momento do conto, assim como a movimentação de Pedro, tem o primeiro círculo aqui apresentado como predominante. Isso pode ser verificado pela recorrência dele na narrativa e pela utilização de elementos que, no primeiro momento, eram diretamente associados a outros círculos. A marca no chão ocasionada pela presença do mendigo sempre no mesmo espaço da calçada pode ser associada à passagem que trata do momento de flerte entre Pedro e a menina: "Os próximos passos eram simples, já estavam pintados no chão" 
(Figueiredo, 2006, p. 47). Da mesma forma, como mencionado na citação destacada, a vagina da menina foi descrita como "uma ferida quente, afunilada" (Figueiredo, 2006, p. 52), também em referência ao mendigo. Outra passagem, mais sutil, relaciona a figura da menina ao círculo dos pais de Pedro, como no trecho em que Pedro encontra a menina no ônibus e consegue, graças à empada, saber seu nome:

A menina deslocou um pouco a mochila que trazia sobre as pernas e se ofereceu para levar, no colo, o saco plástico de Pedro. Ele pôs a sacola sobre as pernas da menina, meteu a mão lá dentro e lhe ofereceu uma empada de palmito. Depois de mastigar com cuidado e soltar um gemido de aprovação, enquanto examinava a metade que ainda segurava entre os dedos, a garota disse como se chamava (Figueiredo, 2006, p. 48).

Essa passagem pode ser associada ao flerte dos pais de Pedro, no primeiro momento da narrativa, e à menção de ambos com relação às empadas, como sendo suas irmãs. Entretanto, nesse segundo momento o flerte vai mais além. O trecho destacado apresenta elementos que permitem associá-la ao ato sexual: primeiramente a menina desloca o que tinha sobre as pernas; em seguida, ela coloca o "saco" plástico de Pedro sobre as pernas; Pedro "meteu a mão lá dentro" para oferecer uma empada, já personificada na própria narrativa, que tinha como sabor palmito, que permite uma aproximação sonora com "pau"; a menina mastiga "com cuidado e solta um gemido de aprovação". A proposição de leitura aqui apresentada pode ser ratificada pela frase subsequente, já no parágrafo seguinte, em que o narrador faz a seguinte afirmação: "A sua irmã, o sangue de sua mãe, a empada os uniu - no nome primeiro, e depois na carne" (Figueiredo, 2006, p. 48).

Foi na união da carne que o círculo se encerrou na narrativa. $\mathrm{O}$ ato sexual, agora realmente consumado, além de ter sido a última ação do conto, foi o momento em que Pedro fez uma reflexão sobre os três círculos do segundo momento e uma projeção para seu futuro.

Pedro, em cima da menina, procurava alcançar o chão. As mãos dela, por sua vez, o puxavam também com força para dentro do chão. E, num relance em que os dois pontos pretos dos olhos da garota fugiram para um lado e depois para o outro, a dois dedos de distância dos seus olhos, Pedro entendeu, de repente, e até viu como havia agora duas luas no mesmo céu. Havia duas moedas, dois fornos, duas mães, dois pais, duas lojas - Pedro viu: eram duas pernas. Teve a certeza de que embaixo de si não havia nada mais do que uma perna. Poderia jurar que martelava sobre uma perna desprendida de qualquer tronco. Entendeu, com perfeita clareza, que se enfiava no centro de uma ferida quente, afunilada, que em resposta aos seus solavancos vibrava, também, lá no fundo, nas raízes de onde manava o sangue. Nessa hora, seu pensamento se negou a manter-se do tamanho da ferida. Rodou sem rumo por alguns segundos, em círculos cada vez maiores, até que se lembrou da discussão que tinha visto dois dias antes, na rua, junto ao muro em frente à escola (Figueiredo, 2006, p. 52).

Essa passagem ratifica a força do terceiro círculo no que se refere ao movimento de expansão do segundo momento do conto mediante o primeiro. Isso pode ser afirmado se a questão numérica da citação for levada em conta: "duas moedas, dois fornos, duas mães, dois pais, duas lojas - Pedro viu: eram duas pernas". Ao mesmo tempo que o movimento de expansão é identificado, também é possível observar que os elementos se repetem, como se fizessem um trajeto circular que lhes garantisse passar pela vida de Pedro recorrentemente.

Além disso, a penetração de Pedro na vagina da menina é associada à circunscrição de Pedro no trajeto circular, a partir do momento em que ele estava numa ferida "afunilada, que em resposta aos seus solavancos vibrava, também, lá no fundo, nas raízes de onde manava o sangue". A associação à ferida da perna do mendigo é inevitável, assim como a rememoração de que "o centro queria engolir a circunferência". É pertinente observar alguns pormenores: trata-se da iniciação de Pedro e da menina na vida sexual, que se confirma pela existência do sangue, que caracteriza o rompimento do hímen. Como uma espécie de ritual de iniciação na vida adulta, o sexo exerceu em Pedro duas percepções: a da expansão com relação ao passado, caracterizada pela duplicação do número, como já dito anteriormente; e a projeção da expansão futura, como se pode perceber em "nessa hora, seu pensamento se negou a manter-se do 
tamanho da ferida. Rodou sem rumo por alguns segundos, em círculos cada vez maiores". Essa frase antecede a conclusão de Pedro de que "a exemplo do outro, aquele mendigo ia acabar morrendo" (Figueiredo, 2006, p. 53) e sua previsão de que

aquela perna embaixo dele era do tamanho da menina, era do tamanho da loja, onde ele entrava até o fundo, cujo espaço todo ele preenchia e de onde, em breve, faria sair empadas muito melhores do que as que sua mãe fazia. Arrumaria a loja de outro jeito, o seu jeito - daquela perna nasceria outra perna (Figueiredo, 2006, p. 53).

Em seu pensamento, Pedro refez e anteviu o trajeto circular ao rodar "sem rumo por alguns segundos, em círculos cada vez maiores". A figura da esfera, determinando o traçado do caminho trilhado por Pedro, introduz a menção aos fatos que o protagonista entendeu como inevitáveis - a morte do mendigo e a própria permanência no espaço da loja de empadas.

A articulação dos três círculos do segundo momento do conto se deu predominantemente pelo terceiro círculo aqui apresentado, pois a reflexão de Pedro sobre o passado e o futuro aconteceu enquanto ele consumava o ato sexual. Esse ato, por estar inconcluso na narrativa, deixa o círculo previsível, porém inconcluso, assim como acontece com os outros dois círculos do segundo momento. Os destinos dos pais de Pedro, dos mendigos, da menina e do próprio Pedro não são definidos, o que permite considerá-los como recomeços constantes no trajeto circular que o menino estabeleceu em seu pensamento.

Importa que se atente para a interseção entre os círculos. Além da figura de Pedro como elemento que transita entre os três círculos de cada momento e, como dito há pouco, de representante da expansão do segundo momento - caracterizado pelo seu crescimento físico -, o narrador faz a articulação entre os círculos de maneira peculiar. Apesar da aparente disparidade entre os elementos de cada círculo, a interrupção a um para a abordagem ao outro é feita com frases que, em alguma medida, sintetizam um círculo e introduzem o outro, como se o narrador não estivesse mudando de assunto e, subitamente, o círculo que vinha sendo apresentado fica esquecido pelo "enganchamento" do outro assunto. Esse recurso - que Rubens Figueiredo utiliza em outros textos - reforça a percepção de circularidade ao estabelecer um elo, uma aliança entre as esferas do conto. Consequentemente, reitera o movimento sem sair do lugar - o andar em círculos.

Uma curiosidade sobre o conto: a proliferação de imagens circulares. Além dos elementos mencionados com eixo dos círculos - a ciranda da escola, as empadas e a ferida do primeiro momento; os olhos e a vagina da menina, o forno e a ferida do segundo momento - outros objetos curvilíneos são mencionados reiteradamente no conto: o alvo, as moedas, a tigela, a lata do mendigo, os dedos curvados e os anéis das clientes, os três olhos da namorada, a cabeça da namorada, a cabeça e as bolhas na cabeça do mendigo, a gota no nariz do mendigo, a cabeça da menina, as paredes curvas do prédio onde os dois namorados se encontravam, a porta de metal da loja. Propositalmente ou não, a esfera perpassa todos os espaços e todas as personagens mencionadas no conto, contribuindo para a sensação de movimento circular, constante, inevitável. De forno a forno.

\section{O tempo rodou num instante nas voltas do meu coração}

A epígrafe deste ensaio, trecho de Roda Viva, de Chico Buarque, nos vem à mente por dois motivos, pela imagem da roda, que "carrega o destino pra lá"; mas também pela sensação de que "o tempo rodou num instante nas voltas do meu coração", com sugere o título desta seção. A roda de Chico Buarque é viva, assim como a roda de Pedro. Viva como a vida que se movimenta sem sair do lugar, andando em círculos. Os movimentos de estreitamento e extensão e a multiplicação dos elementos constitutivos da realidade de Pedro podem ser entendidos como a reiteração dos fatos cotidianos banais, apenas ampliados proporcionalmente ao crescimento do menino. Banais para aqueles que vivem nas classes sociais menos favorecidas, impedidos de transitar para além de seu círculo social. Pedro é uma verdade social, colocada entre parênteses, selecionada para o texto literário. Nas palavras de Wolfgang Iser, 
Se a literatura converte essa plasticidade em forma, o desdobramento desta se torna o espelho do homem, que sempre tenta superar-se a si mesmo. Por este motivo, ela é aquele meio que não só pretende algo, como também mostra que tudo que é determinado é ilusório, inscrevendo um desmentido até nos produtos de sua objetivação. Só assim seu caráter proteico se atualiza. Talvez essa seja a verdade da literatura. Só assim ela resiste a uma consciência que a desmascara como aparência, por já não poder descartá-la como mero engano (Iser, 2013, p. 27).

A forma do círculo, o traço do espirógrafo nas mãos do ficcionista. A vida cotidiana e social ensimesmada, aprisionada no círculo inquebrável, interminável, imutável, inevitável, como as marcas no chão da calçada e da loja de empadas.

\section{Referências}

ADORNO, Theodor W. (2003). Notas de literatura. São Paulo: Duas Cidades; Ed. 34.

BARTHES, Roland (2010). Aula. São Paulo: Cultrix.

BASTOS, Dau [2019?]. O caso Rubens Figueiredo. [S.1.]: [S.n.]. No prelo.

BOSI, Alfredo (2003). Céu, Inferno: ensaios de crítica literária e ideológica. São Paulo: Duas Cidades; Ed. 34.

BOSI, Alfredo (2013). Entre a literatura e a história. São Paulo: Editora 34.

CHEVALIER, Jean (2009). Dicionário de símbolos: (mitos, sonhos, costumes, formas, figuras, cores, números). Rio de Janeiro: José Olympio.

FIGUEIREDO, Rubens (2006). De forno a forno. In: FIGUEIREDO, Rubens. Contos de Pedro. São Paulo: Companhia das Letras.

ISER, Wolfgang (2013). O fictício e o imaginário. Rio de Janeiro: EdUERJ.

MARTINS, Georgina (2013). Narradores da exclusão ou a infância pobre na literatura brasileira contemporânea. Estudos de Literatura Brasileira Contemporânea, Brasília, n. 41, p. 119-148, jan./jun.

PETEL, Karla Louise de Almeida (2015). A importância do banal na ficção literária: uma análise sobre "De forno a forno", de Rubens Figueiredo. In: SENRA, Flávio Pereira; OTTATI, Rafael (Org.). Estéticas contemporâneas em pauta. Rio de Janeiro: Gramma.

STIERLE, Karlheinz (2006). A ficção. Rio de Janeiro: Caetés.

TEZZA, Cristóvão (2006). Horizonte de chão e paredes. Folha de São Paulo, Caderno Mais!, 14 maio 2006. 